\title{
RF POWER SUPPLY SYSTEM FOR ION TECHNOLOGY ACCELERATOR
}

\author{
S.A. Vdovin, N.P. Gladkiy, O.M. Gorajinov, Ye.V. Gussev, V.F. Kovalenko, O.G. Koval, \\ L.D. Lobzov, P.L. Makhnenko, O.V. Manuilenko, E.I. Ponomarchuk, O.P. Podolayk, \\ V.N. Sokil \\ National Science Center “Kharkov Institute of Physics and Technology”, Kharkiv, Ukraine \\ E-mail:vdovin@kipt.kharkov.ua
}

An analytical complex is being created at the NSC KIPT for the study of materials by activation analysis. The design, characteristics and tuning results of the first channel of the high-frequency power supply system of the linear deuteron accelerator are presented. The accelerator will be used as a driver of the neutron source. The system will provide input into the resonator up to $500 \mathrm{~kW}$ of RF power.

PACS: 29. 20. Ej

\section{INTRODUCTION}

A neutron source with an output of $\sim 4 \cdot 10^{11} \mathrm{n} / \mathrm{s}$ is created in the NSC KIPT for the activation analysis of the elemental composition of materials. The deuteron accelerator with an energy of $\sim 3 \mathrm{MeV}$ and an average current of $\sim 200 \mu \mathrm{A}$ will be used as a driver of the beryllium target [1]. The stability of the motion of the beam particles during the acceleration process will be carried out by the method of modified alternating-phase focusing [2]. The high-frequency (RF) power supply system should provide not only the excitation in the resonators of the level of RF field required for acceleration, but also its stabilization, since the beam takes a significant share of the power input into the resonators. Currently, work is underway to debug the first channel of the power supply system on the resonator of the previously created accelerator MLUD-3 [3].

\section{CONSTRUCTION OF HIGH-FREQUENCY POWER SUPPLY}

A high frequency power system is created on the basis of RF generators at a frequency of $150 \mathrm{MHz}$ [4]. The $\mathrm{RF}$ power of the resonators of the accelerating structure is supplied by two RF power sources (Fig. 1) operating in pulse mode. The main parameters of the RF system are as follows:

Main frequency, $\mathrm{MHz}$..................... 100.0;

RF pulse duration, $\mu$ s . ............... $\sim 250 \ldots 350$;

Pulse frequency, $\mathrm{Hz}$..................... 1...25;

The pulse power of the resonator $\mathrm{P} 1, \mathrm{~kW} \ldots \ldots \sim 300$;

Pulse power of the resonator $\mathrm{P} 2, \mathrm{~kW} \ldots \ldots \ldots . \sim 500$;

Field level instability, $\% \ldots \ldots \ldots \ldots \ldots \ldots \ldots \ldots . \pm 1.0$;

Field phase instability, degrees ................ \pm 1.0 .

The high frequency power supplies of the accelerator sections are formed by powerful amplifying channels. In the positive feedback circuits of the amplifier channels, the corresponding resonators are included. This inclusion provides excitation in the resonators of RF oscillations at operating frequency. This mode is used for tuning and training RF resonators with power. In particle acceleration mode, for the synchronization of the RF oscillation phases and frequency identity, the excitation of the second channel is carried out by a signal taken from the first resonator.

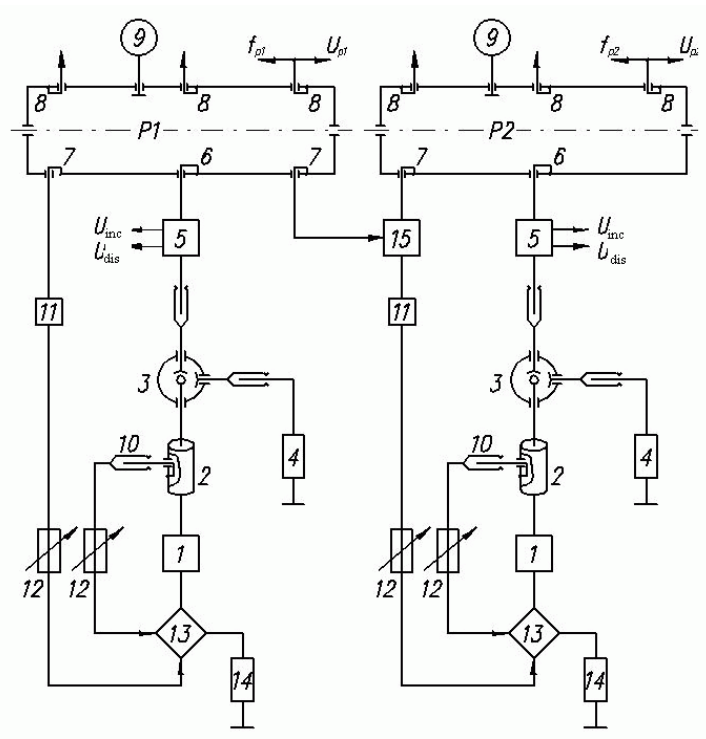

Fig. 1. Flowchart of the RF Power System: 1 -is a channel that is reinforcing; 2 - is a feeder path; 3 -is a feeder switch; 4 -is a load resistance; 5 - reflectometer; 6 -loop of RF power input; 7 -loop of communication; 8 -control of RF field parameters in the resonator; 9 -tuning the frequency of the resonator; 10 -loop communication; 11 -attenuator; 12 -phase shifter; 13 - bridge assembly; 14 - ballast resistance;

15 - feeder switch; $P 1$ and $P 2$ resonators

The system consists of the following main nodes:

- cascade power amplifier;

- resonator $\mathrm{P} 1$;

- feeder power transmission coaxial type;

- a driving generator;

- positive feedback circuits;

- other elements of the RF tuning system (loops, phase rotators, bridges of power, control circuits).

The required RF power level was set by three gain stages. The first stage is assembled on a GU-96B lamp - a powerful generator triode in ceramic metal design with direct voltage cathode and external anode with air forced cooling. Maximum permissible lamp power not less than $2 \mathrm{~kW}$ at frequencies $86 \ldots 250 \mathrm{MHz}$. The peculiarity of this lamp is that it can operate in pulse mode. This allows the lamp output to be increased to $5 \mathrm{~kW}$ by increasing the anode voltage. The lamp was chosen to replace the GU-37B lamp, which was used in the first and second stages of amplification of the base generator 
and whose output was stopped. The lamp was chosen according to the similarity of electrical and geometric parameters. The second stage is made on the GI-43A lamp - a powerful generator tetrode with forced air and water cooling with a pulse power of up to $500 \mathrm{~kW}$. The use of a tetrode instead of a triode is a feature of this amplifier cascade of the generator. This allows in the scheme with the common grid to increase the gain coefficient to 13 (instead of 6 according to the passport data). The third cascade is made on the GI-24A lamp - a powerful generator tetrode with a forced air and water cooled, with a power of up to $1 \mathrm{MW}$ per pulse. The driving generator is made on the basis of the first stage of the base generator. A coupling loop is built into the anode circuit of the cascade, from which a highfrequency signal arrives at the input of the same cascade into the cathode circuit. The tuning element in the selfexcitation mode is a variable capacitor, which is included in the cathode circuit.

The acceleration and focusing channel of the analytical complex is calculated at a frequency of $\sim 100 \mathrm{MHz}$. Therefore, there was a need to change the frequency characteristics of the anode-grid circuits of all stages of amplification of the basic RF system. First of all, the generation frequency was adjusted. In the first cascade, the frequency change was achieved by connecting additional capacities in the anode-grid circuit. In the second and third cascades frequency change by increasing the length of the anode frames, which are the inductance of the oscillating circuits. To protect the screen grid of the tetrode in the second stage, an additional link between the anode and the grid was arranged. Then, in the cathode circuits of all three stages, the inductance of the throttles in the excitation circuits of the generator lamps was increased. In addition, the seats, connection flanges, contact sockets and other elements required for the new generator lamps were manufactured. The connection of the output stage with the feeder and between the stages is realized by means of inductive loops with compensation capacitors. To align the input resistance of the resonator with the wave impedance of the feeder, two quarter wave short-circuit stubs are installed. Control of the power transmission mode is carried out by a reflectometer, which is a pair of inductive loops. The loops are inserted inside the coaxial conductors to obtain signals proportional to the amplitudes of the incident and reflected waves. RF power from the end stage of the generator is transmitted to the resonator through a feeder path with a wave resistance of $50 \mathrm{Ohms}$. Control of the magnitude of the field and frequency in the resonator is carried out on the voltage signals from the loops Urez and frez. Adjusting the frequency of the resonator within $600 \mathrm{kHz}$ is performed by the frequency tuner. It is a short-circuited loop of copper wire $\varnothing 5 \mathrm{~mm}$, placed inside the resonator. The feeder switch allows the RF power to be transmitted quickly both to the accelerator resonator and to the equivalent resistance in the RF tuning mode.

For stable operation of the accelerator and restraint of multipactor processes and discharges in its structures, a scheme with independent circuits of positive feedbacks was used $[5,6]$. Usually a scheme with two positive feedbacks is used. For example, in a resonant E- type structure, with a series connection of acceleration gaps (Alvarez structure), the voltage from the input to the accelerating structure is applied to one amplifier channel and the voltage from the output to another [7]. Such a simple scheme cannot be used to excite RF fields in H-type resonance structures, with parallel coupling of accelerating gaps. Electronic closure of any of the acceleration gaps in such a structure leads to a sharp drop in the value of the resonant resistance of the structure and, as a consequence, the longitudinal electric field [8]. The voltages on the communication elements in the positive feedbacks circuits become so small that the impact of the feedback is destroyed. In H-type resonance structures communication element of the secondary circuit of positive feedback is connected to the power transmission path and is installed at the point of minimum connection with the standing waves of the main type of oscillation in the power transmission path [6].

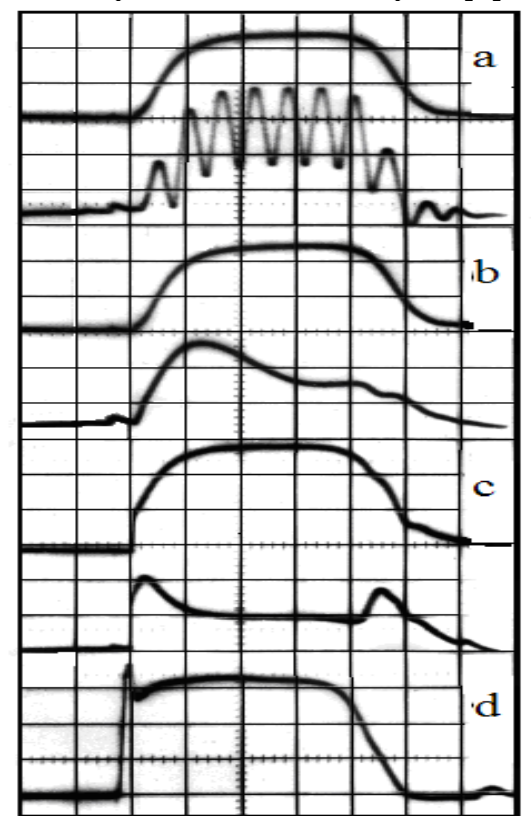

Fig. 2. RF oscillograms with two positive feedbacks: $a, b$-control voltages of the resonator $U_{R E Z}$ (upper) and frequency mixer $U_{M I X}$, at the disorder of $20 \mathrm{kHz}$ (a) and 0 (b). Scale $U_{R E Z}-5 \mathrm{~V} / g . m . ; U_{M I X}-0.5 \mathrm{~V} / \mathrm{g} . \mathrm{m}$.;

$c$-control voltages of the incident $U_{I N C}$ (upper)

and of the displayed $U_{D I S}$ (lower) wave feeder.

Scale $U_{I N C}-10 \mathrm{~V} / g . m . ; U_{D I S}-5 \mathrm{~V} / \mathrm{g} . \mathrm{m} . ;$

$d$-modulator voltage: $U-5 \mathrm{~V} / g . m$., scale horizontal: $50 \mu \mathrm{s} / \mathrm{g} . \mathrm{m}$

The voltages from the communication loops (7) and (10), located, respectively, in the resonator and feeder path are fed through the phase rotators (12) to the bridge assembly (13) and then to the coordinated input of the first channel of the amplification stage. The amplified signal from the output stage on the feeder path coaxial type $160 / 70 \mathrm{~mm}$ in size through the feeder switch (3) is fed into the resonator P1. Changing the frequency of each of the gain stages is carried out by moving anode pistons and allows you to operate at frequencies from 90 to $110 \mathrm{MHz}$.

Adjustment of the mode of transmission of power from the generator to the resonator is carried out by two matching stubs, located a quarter of a wave from the 
loop of power input into the resonator, which allows to compensate for the inductive nature of the resistance of the loop. Fig. 2 shows the oscillograms of the RF voltages when operating the generator in the mode with two positive feedbacks.

The oscillograms characterize the satisfactory stability of the RF power supply system of the first accelerator resonator. Measurements performed by the calorimetric method showed, that at the anode voltage of the modulator $6 \mathrm{kV}$, in the consistent mode, when the SWR $\geq 1.06$ an output power of the RF system of not less than $300 \mathrm{~kW}$.

\section{REFERENCES}

1. S.A. Vdovin, Ye.V. Gussev, P.A. Demchenko, N.G. Shulika. Linear deuteron accelerator for elemental analysis // Problems of Atomic Science and Technology. 2010, № 2, p. 29-33.

2. N.A. Khizhnyak, Ye.V. Gussev. The study of alternating-phase focusing in linear proton accelerators // XIV meeting on charged particle accelerators, October 25-27, 1994, Protvino, Papers of the 14th meeting on charged particle accelerators / IPHE, Protvino. 1994, v. 3, p. 33-43.
3. Ye.V. Gussev, V.N. Derepovskiy, et al. The study of the accelerating structure of the deuteron accelerator MLUD-3 // Problems of Atomic Science and Technology. Series "Nuclear Physics Research". 1989, № 5(5), p. 37-39.

4. Ye.V. Gussev, L.D. Lobzov, V.V. Mitrochenko, N.G. Shulika. The RF power supply system of a small proton accelerator // Problems of Atomic Science and Technology. Series "Technique of a Physical Experiment”. 1986, № 1(27), p. 17-20.

5. L.D.Lobzov, N.G. Shulika. Method of Supp-ressing the Multipactoring Discharges // Problems of Atomic Science and Technology. Series «Nuclear Physics Investigations». 2002, № 2(40), p. 93-94.

6. L.D. Lobzov, et al. Patent of Union of Soviet Socialist Republics №1700783 High frequency generator // Discoveries. Inventions. 1991, № 47.

7. L.V. Alvarez at al. Berkeley Proton Linear Accelerator // The revive of Scientific Instruments. 1955, v. 26, № 111, p. 128.

8. L.D. Lobzov, P.A. Demchenko, N.G. Shulika, et al. The effect of multipactor discharges on the stability of the establishment of accelerating fields of a single-cavity linear ion accelerator // Bulletin of Kharkov University. Series "Nucleus, Particles, Fields". 2003, v. 1(21), № 585, p. 78-84.

Article received 30.10.2019

\title{
СИСТЕМА ВЧ-ПИТАНИЯ ТЕХНОЛОГИЧЕСКОГО УСКОРИТЕЛЯ ИОНОВ
}

\author{
С.А. Вдовин, Н.П. Гладкий, А.М. Горяинов, Е.В. Гусев, В.Ф. Коваленко, А.Г. Коваль, Л.Д. Лобзов, \\ П.Л. Махненко, О.В. Мануйленко, Е.И. Пономарчук, А.П. Подоляк, В.Н. Сокол
}

В ННЦ ХФТИ создается аналитический комплекс для исследования материалов методом активационного анализа. Представлены: конструкция, характеристики и результаты настройки первого канала системы высокочастотного (ВЧ) питания линейного ускорителя ионов, используемого в качестве драйвера источника нейтронов. Система будет обеспечивать ввод в резонатор до 500 кВт ВЧ-мощности.

\section{СИСТЕМА ВЧ-ЖИВЛЕННЯ ТЕХНОЛОГІЧНОГО ПРИСКОРЮВАЧА ІОНІВ}

\section{С.О. Вдовін, Н.Р. Гладкий, О.М. Горяінов, С.В. Гусєв, В.Ф. Коваленко, О.Г. Коваль, Л.Д. Лобзов, П.Л. Махненко, О.В. Мануйленко, С.І. Пономарчук, О.П. Подоляк, В.Н. Сокіл}

У ННЦ ХФТІ створюється аналітичний комплекс для дослідження матеріалів методом активаційного аналізу. Представлені: конструкція, характеристики і результати настройки першого каналу системи високочастотного (ВЧ) живлення лінійного прискорювача іонів, що застосовується як драйвер джерела нейтронів. Система буде забезпечувати введення в резонатор до 500 кВт ВЧ-потужності. 